\title{
Giliberto CAPANO \& Michael HOWLETT (Eds.), A Modern Guide to Public Policy
}

Giulia Bazzan

\section{(2) OpenEdition \\ 12 Journals}

Electronic version

URL: https://journals.openedition.org/irpp/2210

DOI: 10.4000/irpp.2210

ISSN: 2706-6274

Publisher

International Public Policy Association

\section{Printed version}

Date of publication: 30 October 2021

Number of pages: 231-233

ISSN: 2679-3873

\section{Electronic reference}

Giulia Bazzan, "Giliberto CAPANO \& Michael HOWLETT (Eds.), A Modern Guide to Public Policy",

International Review of Public Policy [Online], 3:2 | 2021, Online since 01 August 2021, connection on 16 December 2021. URL: http://journals.openedition.org/irpp/2210 ; DOI: https://doi.org/10.4000/irpp. 2210

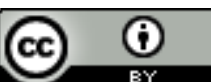

International Review of Public Policy is licensed under a Creative Commons Attribution 4.0 International. 


\title{
Book Review
}

\section{Giliberto CAPANO \& Michael HOWLETT (Eds.), A Modern Guide to Public Policy}

\section{Giulia Bazzan}

Copenhagen University, Denmark

\author{
A Modern Guide to Public Policy \\ Giliberto Capano \\ Michael Howlett
}

Capano, Giliberto \& Howlett, Michael (Eds.), Cheltenham (UK) \& Northampton (USA): Edward Elgar Publishing, 2020, 288 p., ISBN 9781789904970. Hardback: $£ 105.00, \$ 160$; eBook: £25.00, \$40.00 2020 
In the complex and interdisciplinary landscape of public policy, there is an increasing demand for a comprehensive guide to the different approaches and perspectives used to study the policy making process. This timely contribution, edited by Capano and Howlett, gathers the rich body of literature in policy studies within a comprehensive framework. Edited by two of the world's leading scholars in the field, the volume builds on the contribution of both prominent and emerging scholars to make a critical presentation and examination of the state of the art in public policy analysis. The volume guides the reader through the basic definitions of public policy and the major approaches to it, as well as the epistemological and ontological foundations of the discipline. The book successfully combines the theoretical milestones of policy studies and the empirical reality of public policymaking to become an indispensable guide for students, academics and practitioners interested in the question of how to make policies work. This volume is especially poignant on the interface between policy contexts and processes, dealing with the theoretical challenge of opening the black box of public policy. It also shows how different perspectives can be brought together to offer insightful analytical tools that can be used to describe policies and policymaking and to grasp causality and change.

Written in a very thorough and accessible manner, the book consists of 16 chapters and is divided into five parts. The first part (chapters 2, 3 and 4) opens with a discussion of policy elements, processes and actors, which immediately conveys to the reader that public policy is a complex phenomenon, consisting of a variety of actors inside and outside of governmental structures, who make decisions and influence one another. This first part continues with a critical review of the intellectual legacy of the policy cycle model and maps the constellations of policy agents populating the policy process.

The second part (chapters 5, 6 and 7) contributes to the debate over uncertainty and ambiguity. Departing from the contextual factors that influence policymaking, it addresses dilemmas for effective problem-solving and decision-making, opening the floor to a critical review of the multiple streams framework and the development of a more general model of the policy process. Chapter 7 offers a timely toolkit for understanding how and why policymakers often under- or over-react when deciding how to respond to a problem and looks at how it is possible to guide them towards a reaction that is proportionate to the severity of the issue at stake.

The third part (chapters 8, 9 and 10) deals with the complexity challenge in policy studies, showing why and how a mechanistic perspective may be useful for public policy. Acknowledging the increased analytical and theoretical attention paid to mechanisms in the social sciences, chapter 8 discusses the black box problem and its multifaceted nature, advocating a mechanistic turn in public policy. In brief, the black box problem refers to the difficulty of explaining the complexity of public policy and its processual nature. Consequently, the chapter contends that there is a need to focus on explanatory chains and to foster a clear understanding of what makes a difference in the cause-effect relationship inside the black box of the policy process. In this approach, the notion of mechanisms is well positioned to explain how the components of the policy process are interlinked and why they produce a specific outcome. Chapter 9 empirically illustrates such a mechanistic perspective. Chapter 10 examines the nature of policy compliance and its problems. It critically reviews the utilitarian approach of policy design thinking and re-conceptualizes target behavior, thus showing why governments need to have a detailed understanding of the factors affecting compliance and non-compliance in order to combine substantive and procedural policy tools effectively.

The fourth part (chapters 11, 12 and 13) is dedicated to one of the cornerstones of policy studies: policy tools and capacities. The section opens by setting out the foundational definitions of 
policy instruments, reviewing basic taxonomies and introducing the concept of policy mixes, which refers to the design of policies using mixes of instruments. Chapter 12 details the kinds of resources and capacities that governments need to make good policy choices and to implement them effectively. Accordingly, it offers a comprehensive conceptual framework, recognizing multiple capacity types and thus enabling policy analysts to go beyond mere observation on policy capacity. Finally, chapter 13 offers a brief review of the state of the art of the theoretical literature on policy mixes and examines the shift towards the persistent challenge of how and why policy mixes change over time, and whether it is possible to develop strategies to design more effective policy mixes.

The last part of the volume (chapters 14, 15 and 16) is dedicated to policy outputs and outcomes. Chapter 14 organizes the analytical tools of policy design, based on the distinction between the content and the mode of design. In doing so, it first proposes a typology of the content of policy design along the two dimensions of government capacity to design policy and accumulation of policy anomalies that need to be solved. It then offers a conceptualization of two modes of design that enable content: replacement and layering. The next chapter conveys to the reader the value and the explanatory leverage of learning theory to public policy analysis, and the practical lessons of policy learning that can be applied to policy processes, in the effort of bridging the theory-practice divide. Accordingly, three lessons from policy learning are drawn: on the contexts by which learning outcomes are facilitated, on facilitating and hindering conditions, and on dysfunctions of the learning process. The final chapter deals with policy change and the shift from policy dismantling to policy accumulation, highlighting the implication of such a paradigmatic shift in the theorization of public policy. Accumulation allows adaptation, but there is also the potential risk of undermining the legitimacy and effectiveness of public policies.

Taken together, the chapters address a wide range of issues at the intersection of the conceptual, analytical and ontological foundations of the discipline in an accessible manner. The grouping of the chapters works well, with the exception of part three in which policy mechanisms and behaviour are pulled together. The challenge of unveiling complexity is one of the biggest for contemporary policy studies and it would have been more effective to move chapter 10 (about policy target behaviour and compliance) into part five, in which policy outputs and outcomes are discussed, and to dedicate part three exclusively to policy mechanisms.

Finally, every chapter includes a rich bibliography that enables the reader to explore further the topics under examination, thus being a source of inspiration for further theoretical developments and for new research in the field. 